\title{
The Aesthetic Society and Its Gatekeepers
}

Aaron Francis Ward

Faculty of Law, Toyo University

Follow this and additional works at: https://gensoken.toyo.ac.jp/japanese-society-and-culture

Part of the Anthropological Linguistics and Sociolinguistics Commons, Critical and Cultural Studies Commons, Japanese Studies Commons, Linguistic Anthropology Commons, and the Sociology of Culture Commons

\section{Recommended Citation}

Ward, Aaron Francis (2020) "The Aesthetic Society and Its Gatekeepers," Japanese Society and Culture: Vol. 2 , Article 2.

DOI: $10.52882 / 2434-1738-0202$

Available at: https://gensoken.toyo.ac.jp/japanese-society-and-culture/vol2/iss1/2

This Article is brought to you for free and open access by Institute of Social Sciences. It has been accepted for inclusion in Japanese Society and Culture by an authorized editor of Institute of Social Sciences. 


\section{The Aesthetic Society and Its Gatekeepers}

\section{Aaron Francis Ward \%}

'But in Japan, beauty, tradition, poetry, had none of them been touched by the soiled hand of sanctity. Those who touched them and in the end strangled them were quite devoid of sanctity. They all had the same hands, vigorously scoured with soap.'

- Yukio Mishima (2001, 56), The Decay of the Angel

Abstract

The current study draws on Saito's (2007) application to western context of the Japanese practice of appreciating the aesthetic and ethical aspects of everyday objects, examined through the complexity of aesthetic evaluation. Bourdieu's (1984a) moderating variable cultural capital is used to advance an understanding of perceptual and linguistic complexity in daily aesthetic consumption. By engaging participants in a quasi-experiment of multi-sensory trials of everyday products (lemon squeezers), an examination was made of how language use reveals embodied knowledge of daily consumption practice. As the participants' volumes of cultural capital increased, there was a greater tendency to categorize the stimuli according to their formal aspects and use more complex language derived from decorative, ethical and artistic schema. Thus, the logic of everyday aesthetic practice appears to be contingent on contextualized interaction. This research is followed with a discussion of how such inclinations relate to Japanese aesthetic practices in everyday life, by considering the influence of intercultural exchanges and the actions of cultural gatekeepers in Japan and abroad during the development of aestheticized Japanese cultural metonymy in the post-Meiji Restoration era. Further, some discussion is made of the parallel development of the aestheticization of daily practices in Japan and European contexts, and how this likely influenced the cultural context of the research is made. Finally, some of the challenges of instituting an everyday aesthetic as an antidote to the problems generated by mass-consumption society are discussed.

Keywords: Everyday Aesthetics, Cultural Metonymy, Perceptual Complexity, Language use, Cultural Gatekeepers

Introduction

Japan is a country that has a long-running and celebrated tradition of being a nation that values its aesthetic practices. From elegant geisha (芸者) and samurai (侍); to its innumerate world heritage sites, such as the resplendent temples and shrines of former capitals Nara, Kyoto and Kamakura; lush forests and mountainous regions; world-class museums and art galleries; to its world class service and food culture - which includes more Michelin-starred restaurants than the rest of the world combined. There are a number of both Japanese and occidental publications that furnish testimony to the Japanese aesthetic sensibility, such as The Japanese Sense of Beauty (Shuji 2019), and Wabi-Sabi: for Artists, Designers, Poets

\footnotetext{
※ Lecturer,Faculty of Law, Toyo University, Language anthropology, culture consumption, aesthetics.
} 
\& Philosophers (Koren 2008). The Japanese aesthetic view point is also very popular in Western contexts, as exemplified in the curatorial work of Belgian interior designer Axel Vervoodt (2019) who draws on the modest and patinated elements of Japanese form in his work. Indeed, in 2019, Japan was ranked as the number two country, behind Switzerland, for having the richest traditions and cultural heritage in the world by proprietary perception surveys developed and conducted by U.S. News, BAV Group and the Wharton School (U.S. News, BAV Group, and Wharton School 2019, Michelin Guide 2019).

In brief historical context, daily and seasonal aestheticization practices in Japan, such as ohanami ( 花見 cherry blossom viewing), stretch back over 1000 years and are most famously outlined in the courtly life described by Murasaki Shikubu (1981) in the Tale of Genji and the quiet reflection on daily life of the ascetic practices of the tea master Sen no Rikyū. Rikyū espoused humble form and eschewed overembellished and formal perfection in favour of misshapen forms that reflect the process of their creation and reference the people who made them, as a means to harmonious, social communion (Bullen 2010). The sentiment of reflecting upon and appreciating ordinary things also stems from the writings of Kenkō Yoshida, who, in his ascetic Essays in Idleness, lamented the accumulation of ornate objects as 'deplorable' in that '[some things] are probably indispensable to daily life, but as for the rest, it is probably best not to own anything at all.' (Yoshida 1998, 126) Aestheticization practices continued to spread as Japan entered its post-feudal, modern era throughout the Edo Period and produced cultural products now synonymous with Japanese culture, such as kabuki theatre (歌舞伎), geisha and ukiyo-e woodblock prints（浮世絵） (Shively 1995, Rimer 1995, Marra 2001, Bell 2009).

As a consequence, many people believe that this long history of cultural production has led to an unusual degrees of value being placed on the aestheticization of daily practices and mundane objects in Japan (Saito 2007, Hara 2007, 2019, Keene 1982). Although everyday objects are the things people encounter most often, they rarely garner much attention in the West (Norman 1988). In contrast, many Japanese people continue to participate in traditional daily practices such as ohanami, sado (茶道 the Japanese tea ceremony) and onsen (温泉 hot-spring bathing). Every year many visitors to Japan enjoy these, too. Consequently, it is often claimed that the aesthetic concepts of mono no aware (物の哀孔 the pathos and transience of things) and wabi and sabi (侘び寂び simple and patinated) are central elements of Japanese national identity (Richie 2007). This Japanese appreciation of the everyday continues on into the $21^{\text {st }}$ century, as evidenced by the extraordinary number of public institutions, museums and galleries dedicated to all manner of otherwise mundane things, from salt and tobacco to instant noodles and printing. Day-to-day things continue to be aestheticized as a part of Japanese life and are promoted through institutions like the Japan Folk Crafts Museum in Komaba, the d47 Museum and design store in Shibuya, and were recently celebrated in concurrent exhibitions of mingei (民芸 folk crafts) and mingu (民具 everyday objects). These exhibitions were curated by Kenya Hara, the creative director of the global lifestyle brand Muji (無印良品 unbranded fine goods) and the renowned industrial designer Naoto Fukasawa, and were displayed at the avant-garde Tadao Ando-designed 21_21 Design Sight in central Tokyo (21_21 Design Sight 2019b, a, d47 Museum 2019).

In her book Everyday Aesthetics, Yuriko Saito (2007) argues that Japanese practices of aestheticization also offer a unique means to improve the quality of people's everyday lives in places outside of Japan. She feels that aestheticized practices undertaken with consideration and planning in simple daily activity enhance the scope, diversity and inclusivity of artistic practice. According to Saito, there are ethical and 
practical consequences to having an appreciation of the qualities of everyday objects in-and-of-themselves in that people's aesthetic horizons are expanded; hierarchies of value between classifications of objects are broken down; and the ordinary is rendered extraordinary. For example, by applying a wabi-sabi appreciation to the way in which the things around us age - like all things in the natural world - an ongoing relationship is developed with the things around us, whose beauty comes through the recognition of the passing of time that is reified in the object by the beholder. Everyday aesthetics also help to develop ecological literacy, where '...even the seemingly trivial, insignificant everyday aesthetic attitudes and judgements often wield surprising power that can determine the quality of life, the state of the world, or social and cultural ethos in the most literal manner' (Saito 2007, 243).

Saito's (2007) perspective contrasts with western, market-oriented and formalist accounts of industrial design that presuppose that aestheticization is restricted to and facilitated by particular configurations of formal design elements (FDEs) - attributes that are normally seen as extraneous to functional consideration, such as form, colour, shape, materials and so forth. Saito (2007) feels that this occidental perspective, largely predicated on Kant and Hume's art-centred aesthetic, designates that only products of legitimate, fine art culture appeal to the senses in ways that are considered appropriate for disinterested contemplation. In these regards, everyday aesthetics has a commonality with western conceptual art, in that it differs radically from established, received and common-sense notions of artistic or aesthetic value. Further, like conceptual art, everyday aesthetics challenge the idea that the natural homes of aesthetic objects are cultural institutions, such as museums and art galleries (Saito 2007, 14, Hughes 2010, Freeland 2001, Goldie and Schellekens 2009, Forty 1986).

Looking at the image in Figure 1 below, it is easy to see the appeal and promise that the Japanese aesthetic point of view might hold as an antidote to modern mass-consumption culture. The image shows a modestly portioned, simple meal of fish, presented on a humble, earthenware plate, which has been photographed in available, chiaroscuro light, against a rustic tatami mat (毗 Japanese traditional straw floor coverings). Figure 1 lends the viewer a Schopenhauerian, immediate and sympathetic aesthetic point of view that makes no appeal to pecuniary or conspicuous value (Vandenabeele 2007).

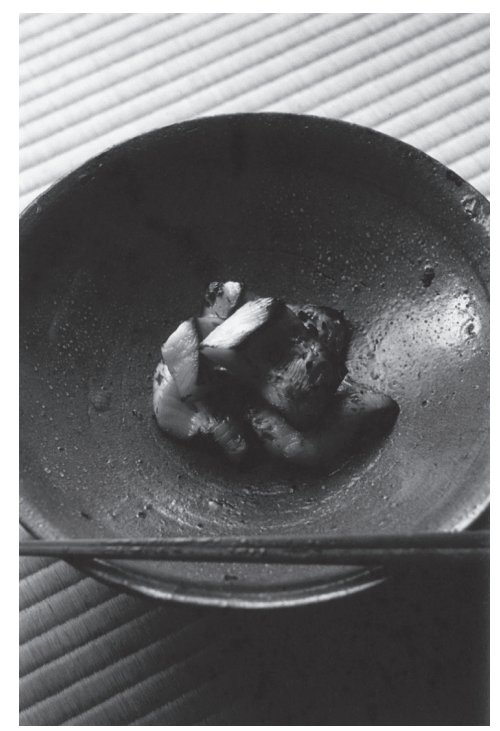

Figure 1 Yoshiko Ueda (2018) 
Although aesthetic tradition continues into modern Japanese society, and is often perceived as metonymy for indigenous culture, it may not be understood by all Japanese people in quite the same way. In 2009, BBC journalist Marcel Theroux visited Japan with an eye to gaining a better understanding of the role of the wabi-sabi aesthetic in Japanese daily life. He soon discovered that while the majority of the people he spoke to on the streets of Tokyo were familiar with the concept of wabi-sabi, most found it difficult to articulate (Theroux 2009). Further, although aesthetic practice, such as ohanami, momijigari (紅葉狩り autumn-leaf viewing) and hanabi (花火 fireworks) continue to be an important, ongoing social practice in Japan, evidence suggests that the focus of such occasions tends to be on communal participation and convivial socializing that invariably attract phenomenal crowds and are assimilated into contradictory, mass-market, commercial interests (Keene 1995, 1982, Koshiro 1995). (See Figure 2 below.)

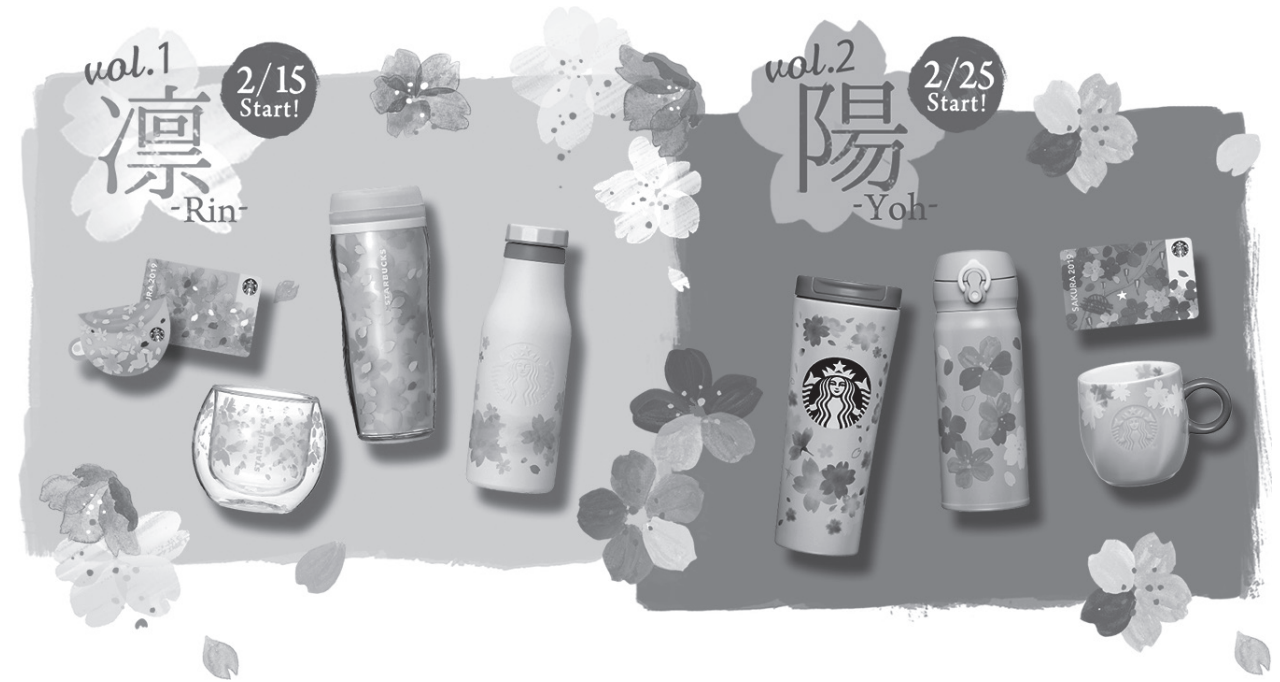

Figure 2 Starbucks Japan Sakuraful promotion (2019)

In tandem with traditional culture, Japan also has massive engine of popular culture industries, including bombastic J-pop, Uniqlo fast-fashion, anime, manga, and pachinko ( パチンコ slot-machine gambling), whose aesthetics could perhaps not be further removed from those of tradition. In contemporaneous respects, Pokemon Go! is probably Japan's most successful cultural export in recent times and has grossed nearly three billion dollars in the three years since its release (Fogel 2019). So, while there is ample evidence that aestheticization practices are important in Japan, the range of forms which these take, like the peoples who live there, are quite diverse.

Aestheticization practices are understood in sociological context as an index of cultural competence and knowledge. This perspective typically posits - as Saito (2007) does, too - legitimate culture at one end of the spectrum of social value and mass, popular culture at the other. Aesthetic competence is an important aspect of social structural reproduction in cultures with established social hierarchies, like Japan, because it is perhaps one of the most difficult forms of social competition to censure, due to its prima facie Kantian disinterestedness (Bourdieu 1993, 1984a, Hughes 2010, Hara and Seiyama 2005). Central to such hierarchical aestheticization is the accumulation of symbolically valuable social skills, which French sociologist Pierre Bourdieu (1984a) describes as cultural capital. This is a form of cultured 
disposition that is acquired and embodied through enculturated familial, academic and occupational contexts. As such, cultural capital is a symbolic form of wealth and marker of social status that necessitates the economic and temporal costs implicit in the acquisition and expression of this disposition. Further, time is a necessary feature of pecuniary distinction precisely because an enculturated disposition cannot be materially exchanged or easily transmitted between social agents (Bourdieu 1984a, Bullen 2010, Veblen 2003, Hughes 2010). In these regards, it seems little surprise that mastering shodo (書道 Japanese ink-brush calligraphy) can take a lifetime, whereas Japanese pop-idol groups such as AKB48 change members and produce and sell records at breakneck speed. While appreciating the things around us more may seem like a reasonable injunction, acquiring the inclination habitually to do so may not be entirely straightforward.

In order to place Saito's (2007) everyday aesthetics in contradistinction to the broader cultural context that it exists within, the aim of the current paper is to examine how mundane aestheticization materializes in New Zealand, a country whose myths of national identity appear to diametrically oppose Japan's. New Zealand was one of the last major landmasses to be permanently inhabited, first by the indigenous Māori peoples, and later by Pākehā European colonists. As a post-colonial society, New Zealand has a national character which centres on a mythology that presents an image of rugged, masculine individualism, tenacious self-determination, utilitarian ingenuity and ironic self-deprecating egalitarianism. Perceptions of New Zealanders are of a people who are rural, independent, practical, modest, good-hearted, honest and fair, yet parochial, narrow-minded, anti-intellectual and with little regard for highbrow culture. To the outside world, New Zealand is the home of pastoral farming, rugby, kiwifruit and Hobbits - none of which are actually endogenous cultural products (Pearson 2005, Liu et al. 2005, Bell 2001, Belich 2001).

Regardless of the substance of myths of national character, aestheticization, like the majority of artistic practice, is amorphous and non-verbal, making it problematic to explore empirically. However, like other social practice, it is inevitably described, historicised and appreciated through language use, in which cultural objects acquire meaning through the experience and ongoing interpellation of objectsign relations in specific social contexts (Bourdieu 1991, Arnold 2004). Building on Wittgenstein's (1922, 1958) propositions that language is contextually dependent and delimits knowledge, Bourdieu (1993, 1991) argues that an allegory can be made between what is said and how it is said with what is seen and how it is seen. Therefore, the aesthetic perceptions of individuals within particular strata in societies can be grasped as an aspect of enculturated choice. This same process of enculturation concomitantly mediates styles of grammar, vocabulary and register, and in doing so, that which is aestheticized and how this is done.

\section{Research Questions}

1. Do people from cultures, specifically one whose national identity (New Zealand) does not centre on aestheticization, also aestheticize daily objects?

2. If this capacity is not the provenance of specific cultural contexts, such as Japan, how can this social logic be understood as an emergent property of global socio-historic context? 


\section{Method}

The current study employed a quasi-experimental design that asked participants to trial a set of lemon squeezers (see Figure 3 below) and then provide open-length written evaluations of their most and least preferred designs. Lemon squeezers were employed because of the variety of design solutions available in terms of functionality (juicing lemons) and FDEs.
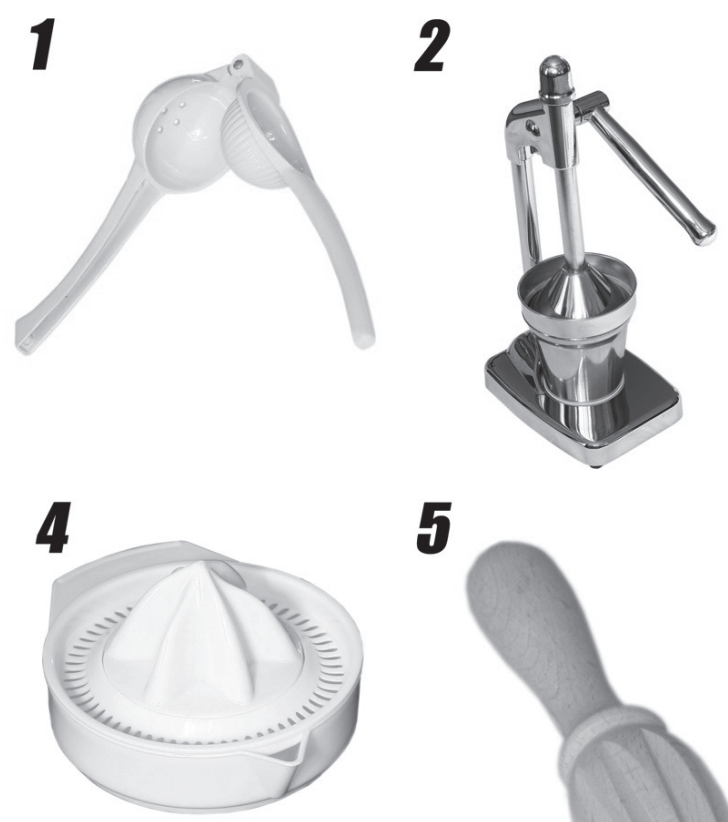

5

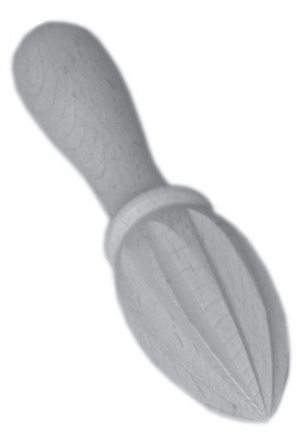

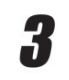
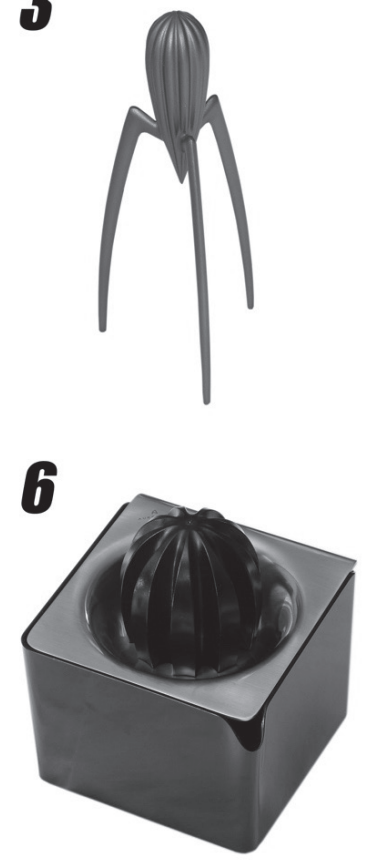

Figure 3 Stimuli

Participants were sorted into low, medium and high cultural capital groupings according to Holt's (1998) formula. The participants were able to trial the squeezers with lemons, and then each participant was given a questionnaire, asking:

1. Which lemon juicer did you like the most, and what features attracted you to it? What was it about these features that attracted you to this lemon juicer?

2. Which lemon juicer did you like the least, and what features did you not like? What was it about these features that you did not like?

The participants' responses were then coded using an adapted version of Caldwell and Woodside's (2003) categorical distinctions and rated according the complexity of the writing structures used. (For more detail on the data coding procedure, please refer to the appendix.)

Results

223 people participated in the study and 32, 149 and 42 participants were assigned to LCC, MCC and HCC groups respectively ${ }^{1}$. The sample had a mean age of 31.91 years (s.d. 13.87 years) and $67.6 \%$ of the

${ }^{1} \mathrm{LCC}=$ low cultural capital, MCC = medium cultural capital, $\mathrm{HCC}=$ high cultural capital 
participants identified themselves as Pākehā. $52.3 \%$ of the participants were female and $44.5 \%$ were male, although there were no statistically significant gender differences on any of the measures taken.

\section{Design Preferences}

The Chi-squared analyses in Table 1 indicate that the design preferences for the MCC and HCC groups, but not the LCC group, are not statistically independent of one another.

Table 1 Design preferences by cultural capital group

\begin{tabular}{lcccccc}
\hline & \multicolumn{3}{c}{ Most Preferred } & \multicolumn{3}{c}{ Least Preferred } \\
\hline \multicolumn{1}{c}{ Desig } & Low & Medium & High & Low & Medium & High \\
\hline$\chi^{2}$ & 10.75 & 35.92 & 13.27 & 7.75 & 31.43 & 17.71 \\
p value & n.s. & $<0.00$ & $<0.0$ & n.s. & $<0.00$ & $<0.00$ \\
\hline
\end{tabular}

Further, Table 2 indicates that only the MCC and HCC groups showed a significantly higher proportion of participants who mentioned both the FDEs and functionality of their preferred designs.

Table 2 Binomial tests for design aspects mentioned x cultural capital grouping

\begin{tabular}{lllll}
\hline Grouping & & \multicolumn{1}{c}{ LCC } & \multicolumn{1}{c}{ MCC } & \multicolumn{1}{c}{ HCC } \\
\hline \multirow{3}{*}{ Preferred } & & \multicolumn{3}{c}{ Proportion \& Significance } \\
& FDE & 0.56, n.s. & $.77, \mathrm{p}<0.00$ & $.77, \mathrm{p}<0.01$ \\
& Functionality & $0.94, \mathrm{p}<0.00$ & $0.84, \mathrm{p}<0.00$ & $0.91, \mathrm{p}<0.00$ \\
Least Preferred & FDE & 0.38, n.s. & 0.57, n.s. & 0.63, n.s. \\
& Functionality & $0.91, \mathrm{p}<0.00$ & $0.86, \mathrm{p}<0.00$ & $0.91, \mathrm{p}<0.00$ \\
\hline
\end{tabular}

\section{Conceptual Complexity}

A one-way ANOVA $\left(\mathrm{F}_{(2,213)}=19.55, \mathrm{p}<0.01\right)$, and Tukey HSD post-hoc analyses comparing the complexity of participant evaluations with cultural capital showed that although generally all of the groups employed more simple criteria than complex ones, the HCC participants made significantly more complex evaluations. Further, Table 3 shows that as cultural capital increases proportionately more sophisticated criteria are used.

Table 3 Percentage of response in each complexity category by cultural capital group

\begin{tabular}{|c|c|c|c|c|c|c|c|c|}
\hline \multirow{2}{*}{\multicolumn{2}{|c|}{ Group }} & \multicolumn{7}{|c|}{ Response Complexity Category } \\
\hline & & 1 & 2 & & 3 & 4 & 5 & 6 \\
\hline LCC & & 69.79 & 13.20 & $\Delta$ & 10.07 & 5.54 & 1.39 & 0.0 \\
\hline MCC & & 57.88 & 19.99 & & 13.24 & 7.25 & 1.18 & 0.44 \\
\hline $\mathrm{HCC}$ & $\downarrow$ & 44.28 & 19.00 & & 16.30 & 15.06 & 3.05 & 2.52 \\
\hline F Ratio $_{(2,213)}$ & & - & 5.297 & & 6.252 & 18.081 & 5.992 & 3.459 \\
\hline $\mathrm{p}$ value & & n.s. & $<0.01$ & & $<0.01$ & $<0.01$ & $<0.01$ & $<0.05$ \\
\hline
\end{tabular}


With the exception of category 1 type responses, there is a significant difference in the number of respective category types made by each cultural capital group. Tukey HSD post-hoc analyses showed that the significant result for category 2 responses was only due to differences between the LCC and HCC group. The significant result for category 3 responses was due to differences between the HCC group and the other two groups. The pattern of results for category 4 - 6 responses was similar to that of category 1 - 3 responses. However, the significant result was attributable to differences between the HCC and the other two groups, for all except category 6 responses, where there was only difference between the LCC and HCC groups.

\section{Evaluation length \& structural complexity}

The t-tests and one-way ANOVAs in Table 4 show that the length of the participants' evaluations increased with cultural capital. Post-hoc Tukey HSD comparisons showed that the significant differences were between the HCC group and the other two groups.

Table 4 Evaluation word lengths and structural complexity by cultural capital group

\begin{tabular}{lcccl}
\multicolumn{1}{c}{ Group } & Most Preferred & Least Preferred & Total & \multicolumn{1}{c}{ t-test } \\
\hline Low & 26.44 & 21.00 & 47.44 & $\mathrm{t}_{(31)}=2.64, \mathrm{p}<0.01$ \\
Medium & 31.11 & 21.36 & 51.67 & $\mathrm{t}_{(140)}=6.92, \mathrm{p}<0.00$ \\
High & 45.84 & 34.42 & 79.51 & $\mathrm{t}_{(42)}=1.86, \mathrm{~ns}$ \\
F Ratio $_{(2,213)}$ & $9.18, \mathrm{p}<0.01$ & $5.26, \mathrm{p}<0.01$ & $8.98, \mathrm{p}<0.01$ & \\
\hline
\end{tabular}

Structural Complexity $\mathrm{F}(2,213)=10.33, \mathrm{p}<0.01$

\section{Discussion}

The results of this study suggest that all of the participants were more inclined to favour functional considerations when evaluating the stimuli, suggesting a general agreement that the products belonged to the same utilitarian family of resemblances (c.f. Wittgenstein 1922). However, in relation to research question one, although the sample of participants was drawn from a cultural context whose cultural metonymy differs markedly from Japan, a significant majority were nonetheless inclined to aestheticize these everyday objects. However, it was only a very specific subset of the participants, who had cultural resources in the form of graduate education, (culturally productive) occupations and family background, who engaged with the stimuli in the abstracted, reflexive way Saito (2007) advocates. It was this smaller group of participants' tendency to aestheticize, in tandem with the complexity and length of their evaluations, that clearly distinguished them from the rest of the participants in the study. Unexpectedly, functionality was the only significant criterion for the evaluation of least-preferred designs for all participant groupings, suggesting that aestheticization practices of everyday objects are not applied in a uniform nor strictly rational way. This underscores the enculturated nature of aesthetic preference in that the participants were probably less familiar with objects not valorised by their subcultural context. Nonetheless, the HCC participants compensated for this apparent gap in cultural knowledge by giving negative evaluations of functionality of compensatorily greater length and complexity.

The most simple evaluations showed no particular aesthetic preference and drew on criteria that were rationalised, perfunctory and agrammatical, such as "it is difficult to use", "it did a good job" 
or "wasted a lot of juice". These evaluations were concrete in nature and, to that end, implied an expectation of agreement on the part of the reader. This result concurs with other studies and suggests that this tendency is reflective of a world-view that is anchored in a working-class narrative: an implicit antagonization of the pretensions of aestheticized, bourgeoisie culture. For the LCC participants, everyday things are designed to do everyday things, and this is how they are seen (Bourdieu 1984a, Holt 1998). When the MCC and, to a significantly lesser extent, LCC participants did aestheticize the squeezers, they tended towards comparably immediate criteria, such as "it's black", or "its cool (sic)". While the MCC participants showed clearer patterns of aestheticization, their evaluations were neither significantly longer nor more complex than the LCCs'. The MCC evaluations often indicated that the squeezers' FDEs were seen as a novelty or gimmick, as in "I liked it because it looks similar to a spaceship from the movie MIIB" of design 3. This suggests a degree of cultural goodwill ${ }^{2}$, marked by Mark Twain's (2010) popular adage 'I don't know much about art, but I know what I like.' This aesthetic orientation seems quite removed from what Saito (2007) might have had in mind.

By drawing on their cultural resources and applying an abstracted, scholastic point of view that is demanded of and reproduced by the top tiers of the higher education system, it was the evaluations of the HCC participants that best indexed Saito's orientation towards everyday objects. Through significantly more structured prose, complimented by measured, poetic language the HCC participants expressed a significant degree of cultural mastery over the mundane. They variously described the squeezers as "aggressive", "humorous" and "sober" and drew on modernist ideology, with open-coded language that articulated perceptions of "simple, clear lines" that were "balanced to look at" (Bernstein 2003, Bourdieu 1991, 1984a, 1993).

Many of the HCC participants also showed insight into Saito's (2007) progressive agenda and John Ruskin's (2003) truth-to-materials ethic. This was exemplified by one participant's preference for design 5, who wrote, "I will pay for natural over plastic as long as the quality is excellent." Other HCC participants took the task of aestheticization to its legitimate cultural conclusion by denoting the squeezers as "object d'art" and "sculptures." Some even demonstrated specific knowledge of the western socio-historic context of everyday aestheticization by identifying the " tilt at the $19 \mathrm{C}$ William Morris-inspired Arts and Crafts movement - with its injunction to fill one's life with things beautiful, even utensils." What clearly distinguished the tenor of the HCC evaluations from the other participants' was succinctly summarised by one HCC participant who suggested, “[design 3's] aesthetics make it look like an artwork rather than a functional tool [...] I equate good-craftsmanship with thoughtfulness in marrying concept and use.” The significantly greater length and complexity of the HCCs evaluations indicate a willingness for these participants to commit time to what common sense deems an inane task, thus suggesting that the opportunity to voice opinions on everyday life was rewarding in-and-of itself for many of the HCC participants. There was also a notable contiguity between the more nuanced evaluations and the kinds of ideas popularized in coffee table staples on the aesthetics of daily life, including those from Japan, like Hara's (2019) One Hundred Whites (百白) and Yanagi's (2017) Selected Essays on Japanese Folk Crafts, and their western equivalents in Alain de Botton's (2006) The Architecture of Happiness and Terrence Conran's

2 Bourdieu (1984a) describes cultural goodwill as the tendency for dominated social class fractions to valorise and reproduce aspects of legitimate culture (art, classical music, literature, etc.) that they do not participate in or understand particularly well, and which they may well be excluded from. 


\section{(1996) On Design.}

These results raise the questions of why it is that two contexts, Japan and New Zealand, which vastly different in socio-historic circumstance and myths of cultural metonymy appear to have commonalities pertaining to everyday aesthetics. Perhaps, as the results of this study indicate, and as Bourdieu (1984a) suggests, the kinds of sophisticated and cultivated aestheticization practices that Saito (2007) advocates are not a cultural function of ethno-specific contexts, but rather of socio-cultural structures that are common to most post-feudal societies. As research in a variety of contexts suggests, aestheticization in New Zealand, and most likely Japan, too, resides in the institutionalized rules and practices that entrench objective perceptual hierarchies within social structures. These hierarchies lead to the establishment of aesthetics discourses and practices that reproduce the domains of the upper tiers of society as legitimate culture (Bourdieu 1984b, 1993, Holt 1998, Bennett, Emmison, and Frow 1999).

To best address the second research question posed by this research, it is important to have a contextualized understanding of the underlying social logic of aesthetics-as-cultural-metonymy. In this regard, it is useful to see the establishment of this ideology as part of an ongoing process of the exchange, appropriation and assimilation of ideas across a history of socio-cultural transformations in which both Japan and New Zealand participate. These transformations are the result of the decline of traditional feudal systems, as happened in both Japan and the West, dating from approximately the $16^{\text {th }}$ century onwards. Take, for example, Japan's Edo period and Florentine Italy: During these periods both countries saw a shift in socioeconomic power towards upwardly mobile, merchant social-class fractions. At the same time, there was a concurrent separation of art from craft, and the evolution, establishment and legitimisation of secularised, independent systems of cultural production. While these cultures are substantively and formally different, both contexts entered a period of social and aesthetic change that legitimized previously sanctioned-against and derogated subcultural forms. This can be seen in the reintegration of pagan forms spliced with Old Testament mythology in Italian Renaissance art, and the shift from noh to kabuki theatre in Japan. These transformed into what have come to be understood in modern culture as fine art in the West, and legitimized Edo culture in modern Japan (Bell 2009, Shiner 2001). These social structural transformations also ushered in Thorstein Veblen's (2003) canon of pecuniary taste, where displays of wealth and fashion became new indices of social status and, as such, influenced consumption practice. Rikyū's wabi-sabi aesthetic, which was in reality the cultural domain of the Japanese elite and upper-middle class of the time, prefigured and countenanced the rise of conspicuous consumption in the Tokugawa Period. Veblen's critique of the leisure class was similarly directed at censuring the decadent values of the upwardly-mobile in late nineteenth century Europe. Rikyū's and Veblen's perspectives share a great deal with Saito's (2007) by targeting a perceived lack of cultural sophistication in the tastes of those climbing the social ladder (Bourdieu 1984a, Holt 1998, Bell 2009, Shively 1995, Shiner 2001, Riello and McNeil 2016, Ikegami 2014, Miller 2011). ${ }^{3}$

As a continuation of this process of social change, in the late-modern era, the notion of a specifically Japanese aestheticization of daily life is perhaps better viewed as a consequence of an ongoing process of parallel cultural development since the 1868 Meiji Restoration. Global trade at the time led to cultural

\footnotetext{
3 The same critiques can still be seen in contemporary debates about the massification of luxury brands and mass tourism (MacCannell 1999, Shiner 2001, Saito 2007).
} 
exchanges as Japan exported its culture to the West and western ideas were imported into Japan as part of the Wakon-yōsai movement (和魂洋才 Japanese mind with occidental knowledge). This era ushered in a more widespread aestheticization in daily life that coincided with global-scale changes in trade and industrialisation and the emergence of the middle class. However, it was perhaps following the introduction of western aesthetics (美学 bigaku) as an subject of philosophical pursuit that facilitated the emergence of aestheticization practices as a prominent cultural metonym for Japan to establish its identity on the global stage (Marra 2001, Kikuchi 2004).

By the mid-to-late $19^{\text {th }}$ and early $20^{\text {th }}$ centuries, the Japanese aestheticization of daily objects had broadened its scope, in part due to the rise and marketability of orientalism in the West that spawned Japonism and fed into the western avantgarde arts' scene (Said 2007, Hook 2014). At the same time as this form of cultural production was entering its penultimate phase in the West, Soetsu Yanagi and other proponents, such as Daisetz Suzuki, Kitaro Nishida, and Keizo Shibusawa were influencing the institutionalization of the aestheticization of mundane objects in early twentieth century Japanese culture, through the mingei and mingu movements. These movements reappropriated and assimilated orientalist ideology as an aspect of Japanese culture that, like Rikyū 400 years earlier, extolled and augmented the aesthetic value of modest, practical and hand-crafted goods and a post-Kantian detachment of muga (無 我 no self) (Kikuchi 2004). Despite Yanagi's claim to an original Japanese aesthetic, his ideas were researched and developed based on ideas of the British Arts and Crafts movement, pioneered by William Morris and John Ruskin. In the spirit of Rikyū and Veblen before them, Morris and Ruskin lamented the quality and social implications of mass-produced goods in the machine age. Nonetheless, Yanagi (2017) set about his stated mission to revive a distinctly Japanese folk craft, intended to foster a sense of national identity based on traditional Japanese concepts of beauty. Yanagi and his adherents are by no means alone in this apparent cultural sleight-of-hand. The suspiciously entitled In Praise of Idleness, by respected British utilitarian philosopher Bertrand Russell (2004), also exalts the merits of a reflective, preindustrial life yet makes no acknowledgement whatsoever of the preceding works of Kenko or Junichiro Tanizaki's In'ei Raisan (陰籍礼讃 In Praise of Shadows), which outlines the delicate, unassuming nature of the aesthetics of the traditional Japanese house. Tanizaki most famously describes the quiet virtues of the washiki (和式 traditional Japanese toilet) as an index of the inalienable nature of Japanese aesthetic sensibilities - something that occidental commonsense ought to hold as being well outside the realms of aesthetic consideration. However, history again demonstrates that such wistful bathroom poetics are not something specifically Japanese, nor entirely original. In fact, the Dada artist Marcel Duchamp had pulled the same cultural rabbit from his hat some 15 years earlier with his seminal readymade artwork Fountain. This artist-signed, production men's urinal has since been heralded, fin de siècle, by the Turner Prize jury as the most important artwork of the $20^{\text {th }}$ century in the western canon (Goldie and Schellekens 2009, Dutton 2009).

Further to research question two, by the early-to-mid $20^{\text {th }}$ century, western design ideologies, such as Walther Gropius' German Bauhaus movement, had begun to appropriate formal elements from Japanese washitsu (和室 traditional rooms). The Bauhaus, in the spirit arts and crafts movements, was also a progressive movement that, like Saito's (2007) everyday aesthetic, aimed to integrate art and craftwork into the design of everyday life. The formal elements of traditional Japanese architecture were esteemed by pioneering architects, such as Frank Lloyd-Wright, and were central to the development 
of the international style. It was also a program that attracted a number of Japanese students who, in turn, reappropriated these ideas back into modern Japanese design. Ironically, perhaps the most notable proponent of the Japanese international style was Yanagi's own son, Sori Yanagi, the designer of the Vitramanufactured Butterfly Stool. The legacy of this cultural exchange continues to influence Japanese design, particularly in the products of the quintessential Japanese brand, Muji. Finally, it must also be noted that Saito's (2007) philosophy shares a number of remarkable similarities with the German existentialist, psychoanalytic writer, Erich Fromm, in his antimaterialist work To Have or to Be (Shiner 2001, Čapkova 2017, Maasberg 2019, Wright 2003, Keeps 2014, Fromm 2005).

Although the preceding discussion is by no means exhaustive, it does provide evidence that the modern Japanese aesthetics of daily life did not develop in isolation, but rather are part of a broader process of global intercultural appropriation and exchange. This may also help to show why people with quite divergent cultural metonymies, such as New Zealand (with influence from its own European heritage) and Japan, are sympathetic to the notion of an everyday aesthetic.

In order to understand the possibilities of Saito's (2007) progressive ideals for contemporary consumer culture, it is necessary to consider the relationship between consumers and what they consume with the socially embedded nature of the ideas that underlie consumption practice. Bourdieu (1993), in his work The Field of Cultural Production, outlines an understanding of how, in simple terms, cultural products are created and distributed across societies according to the relationship between the location in social hierarchy of cultural producers and their consumers, and how this is effected by the influence of cultural intermediaries known as cultural gatekeepers. Cultural gatekeepers include, but are not restricted to, people who influence the social valuation of cultural products and the meaning attached to them in some way that increases or decreases the exchange value of these goods in the cultural marketplace. For example, today's social media influencers and celebrity-endorsers act, in part, as gatekeepers of popular culture by communicating their opinions of popular cultural goods to the mass market. In contrast, the gatekeepers of legitimate culture are people associated with venerated positions in society such as museum curators, art gallerists, dealers and critics, as well as the mechanisms of social institutions, including museums and the upper echelons of the tertiary education system (Bourdieu 1993).

Taking a critical eye to Figure 1 can help us to gain a better understanding of the role of cultural gatekeepers and the latent economic foundations of legitimate aestheticization practices in the Japanese context. The photograph was taken by renowned Japanese photographer and Tama University fine-arts professor, Yoshihiko Ueda, at the two-starred, Michelin Guide restaurant, Seisoka (青草窠) in Tokyo's Minato-ku, a municipal ward that boasts another 110 Michelin Guide restaurants - the highest density of these anywhere in the world (Michelin Guide 2019). Seisoka has no online presence, no fixed menu nor signage or advertising of any kind, and seemingly relies on its reputation within the cognoscenti to attract its clientele. According to Tabelog (2019), Japan's online restaurant guide, an evening meal at Seisoka excluding drinks - costs an eye-watering JPY30,000 to 40,000 per person. Finally, the image was published in Ueda's (2018) The Seasonal Beauty of Japanese Cuisine, which served as the exhibition catalogue for an exclusive Roppongi Hills art gallery. This publication indicates that the plate the dish is served on was made in the Momoyama period (AD 1573 to 1600) - the same era in which Sen no Rikyū was tea master to the powerful feudal lords, Nobunaga Oda and Hideyoshi Toyotomi. Although Figure 1 may present 
something of a peculiar example, it nonetheless illustrates that, in the aesthetic guise, pecunia non olet $^{4}$. What is perhaps most interesting about Figure 1, is that it demonstrates how legitimate everyday aesthetics are a cultural conversation between a specific social class fraction of consumers and producers who share the same ascribed values and occupy roughly the same position in their sociohistorical hierarchy. Murasaki, Rikyū and Veblen, Ruskin and Morris, Yanagi and Gropius, and finally Hara and Saito herself, all come from well-educated, affluent, upper middle-class and cosmopolitan backgrounds. As the results of this study would indicate, these cultural producers and gatekeepers are communicating with people sufficiently enculturated and well-heeled to able to share their aestheticized worldview, whether they are from Japan, New Zealand or perhaps anywhere.

So, what are the prospects for a progressive everyday aesthetic? Saito's (2007) outline of an everyday aesthetic, by connecting Japan's aesthetic practices of the past to a resocialization of modern consumption, actually draws on some distinctly conservative ideas. It is here that a problematic connection can be made between Tanizaki's aestheticization of washiki and Duchamp's Fountain that challenges the prospects of a widespread acceptance of an everyday aesthetic. Everyday aesthetics, of the kind Saito (2007) prescribes, share many of the central concepts and problems peculiar to conceptual art. A reflective appreciation of mundane objects requires a certain self-awareness and an acceptance of anti-definition - a capacity and willingness to engage thoughtfully with objects that would normally lie outside the bounds of a received, popular understanding of aesthetic practice. Framed this way, everyday aesthetics is a philosophical challenge to consumers, which demands a reflective examination of an ontological and epistemological nature. This personal inquiry must be done in the absence of the kinds of surrogate indices, such as medium, context, technique, style and signature that are usually found in the more restricted art market. Consumers in the mass market are thus confronted with the dauting challenge of delineating the kinds of mundane things that might qualify as fodder for aesthetic appreciation and deciphering the manner in which this should be done (Bourdieu 1993, c.f. Goldie and Schellekens 2009). Consider, for a moment, the most popular choice of the aesthetically inclined participants in this study. How is the average person to discern a lemon squeezer from the "symbolic micro sculpture" (Carmel-Arthur 1999, 13) that the designer of stimulus 3, Philippe Starck, described it to be? It is the philosophical nature of an everyday aesthetic and its demands that may ultimately limit its wider appeal. History has already demonstrated that other aesthetically-oriented social programs, such as the Bauhaus, failed to gain acceptance from the working class people whose lives they were supposed to improve, precisely because the underlying philosophical logic alienated people lower down the social structure from their own socio-historical context (Guillén 2006).

This does not mean that Saito's ideas are entirely without merit. Unlike conceptual art, mundane objects do not rely on an appreciation of irony. They typically have an established medium, which in virtue of some degree of discernible functionality, is not 'mere means' to aesthetic appreciation (c.f. Goldie and Schellekens 2009, 24). As the conservative aesthetician Roger Scruton (2001) argues, aesthetic value that is neither kitsch nor wholly reliant on irony, is one which establishes a continuity and connectedness for people between objects of appreciation, spirituality and tradition. Morris' Arts and Crafts movement and Yanagi's mingei are ideologies based in spiritualized, socialist philosophies, whose value lay in

\footnotetext{
4 Money has no smell.
} 
being modern cultural forms that established and maintained a sense of continuity and community by repudiating the alienating aspects of modernity (Scruton 2001, Kikuchi 2004). In these respects, it is the familiarity of contemporaneous Japanese aestheticization practices, like ohanami, that give them the capacity to connect people to their histories, and which allows such practice to serve as a foundation for communal participation. However, it must be underscored that the media for this connectedness are well-established, social institutions that date back centuries. How easily this may be integrated into other cultural contexts remains a matter for further investigation.

\section{Conclusion \& Implications}

This paper begins with a recontextualized quote by the Japanese author Yukio Mishima (2001) from his final novel, The Decay of the Angel, which highlights some of the challenges facing the widespread acceptance of the aestheticization of everyday things. By abstracting a set of ideas rooted in traditional Japanese culture and augmenting them with a philosophically grounded social agenda, the nature of everyday aesthetics has become sacralised, and common-sense views of the function of everyday objects are challenged. In the language of conceptual art, it is the idea idea that has taken centre stage, and it is the aestheticization-of-the-object rather than the object-of-aestheticization that has become the locus of its presumed social value. It is precisely this annexation of popular understanding and taste that, like conceptual art, gives everyday aesthetics its value on the upper tiers of the symbolic market of social exchange. It is precisely this, in turn, that deliberately excludes those from below (Goldie and Schellekens 2009, Bourdieu 1984a). While broadening the reach of traditional Japanese aesthetic practices to social agenda and ethical ends in other contexts certainly has great appeal, evidence suggests that this would require significant, ongoing and expensive social and educational reform. 
Appendix

Participant assignment to cultural capital groups followed Holt's (1998) weighting and formulation, as follows:

cultural capital $=\frac{\text { father's education }+ \text { occupation }}{2}+\begin{gathered}\text { participant's education }+ \\ \text { occupation }\end{gathered}$

Weighting

\begin{tabular}{cll}
\hline Weight & Education & Occupation \\
\hline 1 & high school or less & student, unskilled labourer, housewife, \\
2 & NZQA certificate or diploma & service, clerical \\
3 & Bachelor's degree & sales, technical/trade \\
4 & Master's degree & professional, medical doctor \\
5 & Doctorate & academic, cultural producer \\
\hline
\end{tabular}

An example of Caldwell and Woodside's coding was employed in the current research can be seen below.

\begin{tabular}{cl}
\hline Score & Participant Exemplars \\
\hline 1 & cute, nifty, styly [sic] \\
2 & sophisticated, kinda [sic] new age, looks professional \\
3 & functional appearance, interesting discussion topic \\
4 & superior forms, thoughtful design \\
5 & It's more of an art piece, sober design \\
6 & It's an example of late-modern consumerism, design prosaic overly complex \\
\hline
\end{tabular}

The structural criteria complexity of the participants' evaluations was coded according to the following criteria:

\begin{tabular}{cl}
\hline Score & Descriptors \\
\hline 1 & no structure, ideas written down in no particular order \\
2 & some structure, linking words (etc.) and commas used \\
3 & sentences and punctuation used, informal style (reflecting spoken language), \\
& paragraphing \\
4 & sentences and punctuation used, formal style (reflecting formal written \\
& language) \\
5 & essay form, complex sentence structure, use of subordinate clauses, etc \\
\hline
\end{tabular}


References

21_21 Design Sight 2019a. "Another Kind of Art 民芸 ." accessed September 3.

http://www.2121designsight.jp/en/program/mingei/.

21_21 Design Sight 2019b. "Mingu 民具." http://www.2121designsight.jp/en/gallery3/mingu/.

Arnold, Dana. 2004. Art History, Very Short Introductions. Oxford: Oxford University Press.

Belich, James. 2001. Paradise Reforged: A History of New Zealanders From 1880s to the Year 2000. Honolulu: University of Hawaii Press.

Bell, C. 2001. Sociology of Everyday Life in New Zealand. Palmerston North: Dunmore Printing Company Ltd.

Bell, David. 2009. "Urbane Pleasures." In Pleasure \& Play in Edo Japan, edited by Richard Bullen. Christchurch: The Caxton Press.

Bennett, Tony, Michael Emmison, and John Frow. 1999. Accounting for Tastes: Australian Everyday Cultures. Cambridge: Cambridge University Press.

Bernstein, B. 2003. Class, Codes and Control, Volumes I - IV. 4 vols. Vol. 1-4. London: Routledge.

Bourdieu, Pierre. 1984a. Distinction: A Social Critique of the Judgment of Taste. Cambridge, Massachusetts: Harvard University Press.

Bourdieu, Pierre. 1984b. Homo Academicus. Stanford, California: Stanford University Press.

Bourdieu, Pierre. 1991. Language \& Symbolic Power. Cambridge, Massachusetts: Harvard University Press.

Bourdieu, Pierre. 1993. The Field of Cultural Production. Oxford: Polity Press.

Bullen, Richard. 2010. "Refining the Past." British Journal of Aesthetics 50 (3):243 - 254.

Carmel-Arthur, J. 1999. Philippe Starck. London, England: Carlton Books Limited.

Conran, T. 1996. Terrance Conran on Design. London: Conran Octopus Limited.

d47 Museum 2019. "d47 Museum." accessed September 16. http://www.hikarie8.com/d47museum/. de Botton, A. 2006. The Architecture of Happiness. London, England: Hamish Hamilton.

Dutton, D. 2009. The Art Instinct. UK: Oxford University Press.

Fogel, Stefanie. 2019. "'Pokémon Go' Global Revenue Grew 37\% in 2018 (Analyst)." Variety.

Forty, A. 1986. Objects of Desire: Design and society since 1750. UK: Thames \& Hudson.

Freeland, Cynthia. 2001. Art Theory, A Very Short Introduction. Oxford: Oxford University Press.

Fromm, E. 2005. To Have or to Be?: Continuum International Publishing Group.

Goldie, Peter, and Elisabeth Schellekens. 2009. Who's Afraid of Conceptual Art? London: Taylor \& Francis Ltd.

Guillén, M.F. 2006. The Taylorized Beauty of the Mechanical: Scientific Management and the Rise of Modernist Architecture. United States of America: Princeton University Press.

Hara, Junsuke, and Kasuo Seiyama. 2005. Inequality Amid Affluence. Translated by Brad Williams. Melbourne: Trans Pacific Press.

Hara, Kenya. 2007. Designing Design. Baden: Lars Müller Publishers.

Hara, Kenya. 2019. 100 Whites. Baden: Lars Müller Publishers.

Holt, D.B. 1998. "Does Cultural Capital Structure American Consumption?" Journal of Consumer Research 25:1-26.

Hook, Philip. 2014. Breakfast at Sotheby's: An A-Z of the Art World. London: Penguin Books Ltd.

Hughes, Fiona. 2010. Kant's Critique of Aesthetic Judgement. First ed, Continuum Reader's Guides. London: Continuum International Publishing Group.

Ikegami, Eiko. 2014. Bonds of Civility: Aesthetic Networks and the Political Origins of Japanese Culture. Cambridge: Cambridge University Press.

Keene, Donald. 1982. The Distinctiveness of the Japanese. Tokyo: Asahi Press.

Keene, Donald. 1995. "Japanese Aesthetics." In Japanese Aesthetics and Culture, edited by Nancy G. Hume. Albany: State University of New York Press. 
Keeps, David. 2014. "5 Questions: The Muji catalog of life and design all about simplicity." LA Times. Accessed September 4. https://www.latimes.com/home/la-hm-muji-20140621-story.html.

Kikuchi, Yuko. 2004. Japanese Modernisation and Mingei Theory : Cultural Nationalism and Oriental Orientalism. London: Taylor \& Francis Ltd.

Koren, Leonard. 2008. Wabi-Sabi: for Artists, Designers, Poets \& Philosophers. Berkeley: Stone Bridge Press.

Koshiro, Haga. 1995. "The Wabi Aesthetic through the Ages." In Japanese Aesthetics and Culture: A Reader, edited by Nancy G. Hume. Albany: State University of New York Press.

Liu, J.H., T. McCreanor, T. McIntosh, and T. Teaiwa. 2005. New Zealand Identities: Departures and Destinations. New Zealand: Victoria University Press.

Maasberg, Ute. 2019. "The purity of design: How Japan influenced the Bauhaus - and the effects the art school had on Japan ". deutschland.de, accessed July 4. https://www.deutschland.de/en/japan-and-the-bauhaus.

MacCannell, Dean. 1999. The Tourist: A New Theory of the Leisure Class. 1989 ed. Berkeley: University of California Press.

Marra, Michael F. 2001. A History of Modern Japanese Aesthetics. Translated by Micheal F. Marra. Honolulu: University of Hawai'i Press.

Michelin Guide. 2019. "Michelin Guide 2019." Michelin Guide, accessed September 2. https://gm.gnavi.co.jp/home/.

Miller, Mara. 2011. Japanese Aesthetics and the Philosophy of Art. In The Oxford Handbook of World Philosophy, edited by Jay L. Garfield and William Edelglass. USA: Oxford University Press.

Mishima, Yukio. 2001. The Decay Of The Angel. London: Vintage Publishing.

Murasaki, Shikubu. 1981. The Tale of Genji. Translated by Edward G. Seidensticker. Auckland: Penguin Books Ltd.

Norman, D.A. 1988. The Design of Everyday Things. USA: Basic Books.

Pearson, D. 2005. "Citizenship, Identity, and Belonging: Addressing the Mythologies of the Unitary Nation State in Aotearoa/New Zealand." In New Zealand Identities: Departures and Destinations, edited by J.H. Liu, T. McCreanor, T. McIntosh and T. Teaiwa. New Zealand: Victoria University Press.

Richie, Donald. 2007. A Tractate on Japanese Aesthetics. Berkeley, California: Stoney Bridge Press.

Riello, Giorgio, and Peter McNeil. 2016. Luxury: A Rich History. Oxford: Oxford University Press.

Rimer, J. Thomas. 1995. "Japanese Literature: Four Polarities." In Japanese Aesthetics and Culture, edited by Nancy G. Hume. Albany: State University of New York Press.

Ruskin, J. 2003. "The Stones of Venice, vol. 2." In The Industrial Design Reader, edited by C Gorman. New York: Allworth Press. Original edition, 1853.

Russell, Bertrand. 2004. In Praise of Idleness: And Other Essays. London: Taylor \& Francis Ltd.

Said, Edward. 2007. Orientalism. London, United Kingdom: Penguin Books Ltd.

Saito, Yuriko. 2007. Everyday Aesthetics. New York: Oxford University Press Inc.

Scruton, Roger. 2001. The Aesthetic Understanding : Essays in the Philosophy of Art and Culture. Indiana: St Augustine's Press.

Shiner, Larry. 2001. The Invention of Art: A cultural history. Chicago: The University of Chicago Press.

Shively, Donald H. 1995. "The Social Environment of Tokugawa Kabuki." In Japanese Aesthetics and Culture, edited by Nancy G. Hume. Albany: State University of New York Press.

Shuji, Takashina. 2019. The Japanese Sense of Beauty. Tokyo: Japan Publishing Industry Foundation for Culture.

Starbucks Japan 2019. "Starbucks Spring Season 2019." accessed May 4. https://www.starbucks.co.jp/coffee/190215/index.html?nid=coarc.

Tabelog 2019. "Seisoka." Tabelog, accessed March 7. https://tabelog.com/en/tokyo/A1307/A130703/13090635/.

Theroux, Marcel. 2009. In Search of Wabi Sabi. In Hidden Japan: BBC. 
Twain, Mark. 2010. The Innocents Abroad (Wordsworth Classics). First ed. Ware, Hertfordshire: Wordsworth Editions Ltd.

U.S. News, BAV Group, and Wharton School. 2019. "Best Countries 2019: Global rankings, international news and data insights." U.S.News \& World Report LP, accessed September 16. https://media.beam.usnews. com/55/57/eb2338c7493eadf38e29db4b8dca/190116-best-countries-overall-rankings-2019.pdf.

Ueda, Yoshihiko. 2018. The Seasonal Beauty of Japanese Cuisine. Tokyo: Kyuryudo Art Publishing Co., Ltd.

Vandenabeele, Bart. 2007. "Schopenhauer on the Values of Aesthetic Experience." The Southern Journal of Philosophy XLV:565 - 582.

Veblen, T. 2003. "The Theory of the Leisure Class: An Economic Study of Institutions." In The Industrial Design Reader, edited by C. Gorman. New York: Allworth Press.

Vervoodt, Axel. 2019. "Axel Vervoodt." accessed August 6. https://www.axel-vervoordt.com.

Wittgenstein, Ludwig. 1922. Tractatus Logico-Philosophicus. Translated by C. K. Ogden. London: Kegan Paul, Trench, Trubner \& CO., LTD.

Wittgenstein, Ludwig. 1958. Philosophical Investigations. Translated by G. E. M. Anscome. Third ed. Oxford, UK: Basil Blackwell Ltd.

Wright, Frank Lloyd. 2003. "The Art and Craft of the Machine." In The Industrial Design Reader, edited by Carma Gorman. New York: Allworth Press.

Yanagi, Soetsu. 2017. Soetsu Yanagi: Selected Essays on Japanese Folk Crafts. Tokyo: Japan Publishing Foundation for Culture.

Yoshida, Kenko. 1998. Essays in Idleness : The Tsurezuregusa of Kenko. Translated by Donald Keene. New York: Columbia University Press.

Čapkova, Helena. 2017. "The Bauhaus and the Tea Ceremony: A Study of Mutual Impact in Design Education between Germany and Japan in the Interwar Period." In Eurasian Encounters, edited by Carolien Stolte and Yoshi Kikuchi. Amsterdam: Amsterdam University Press. 